\title{
Annual Index
}

Authors

Alfonso BC. (See Ehrenkranz NJ).

(See Eckert DG.)

Anderson JR. (See Horsburgh CR Jr).

Anderson RL. Iodophor Antiseptics: Intrinsic Microbial Contamination with Resistant Bacteria (Editorial). 10(10):443-446.

Andres N. (See Hamill RJ).

Athar MA. (See Wright JB).

Baker AS. (See Hibberd PL).

Barker G. (See Ford-Jones EL).

Beck-Sague CM, Jarvis WR. Epidemic Bloodstream Infections Associated with Pressure Transducers: A Persistent Problem. 10(2):54-59.

Beers LM, Burke TL, Martin DB. Shigellosis Occurring in Newborn Nursery Staff 10(4):147-149.

Belcuore TR. (See Raad II).

Bentley DW. Current Challenges and Future Opportunities (Topics in Long-Term Care). 10(10): 481-483.

Berlinberg CD, Weingarten SF, Bolton LB, Waterman SH. Occupational Exposure to InfluenzaIntroduction of an Index Case to a Hospital. 10(2):70-73.

Binnion B. (See Moore PJ).

Bridge J. (See Thomas JC).

Birnbaum D. Cross-Sectional Survey Sampling (Letter to the Editor). 10(11):502.

Brown EA, Talbot GH, Provencher M, Cassileth P. Anaerobic Bacteremia in Patients with Acute Leukemia. 10(2):65-69.

Bobadilla M. (See Zaidi M).

Bohn D. (See Ford-Jones EL).

Bolton LB. (See Berlinberg CD).

Bolyard E. (See Moraleda MH).

Bouvier B. (See Koo D).

Boyko EF. (See Horsburgh CR Jr.).

Bruch MK, Larson E. Regulation of Topical Antimicrobials: History, Status and Future Perspective. 10(11):505-508.

Larson E. An Early Historical Perspective on the FDA's Regulation of OTC Drugs (Readers' Forum). 10(11):527-528.

Bryan CS. Surgeon-Specific Wound Surveillance: The Family or the Bean Counters? (Special Commentary). 10(8):376-378.

Asepsis, the Right Touch. Something Old is Now New; Sue Crow (Book Review).10(10):486.

Bryant HE. (See Church DL).

Burke JP, Tilson HH, Platt R. Expanding Roles of Hospital Epidemiology: Pharmacoepidemiology (New Challenges and Controversies). 10(6): 253-254.
(See Larsen RA).

Burke TL. (See Beers LM).

Burmeister LF. Cluster Sampling in Hospital Surveillence (Statistics for Hospital Epidemiology). 10(12):573-575.

Campbell B. Infection Control in Canada (Readers' Forum). 10(3):121-122.

Cassileth P. (See Brown EA).

Chaney-Rowe11 C. (See Crow S).

Church DL, Bryant HE. Investigation of a Streptococcus viridans Pseudobacteremia Epidemic at a University Teaching Hospital. 10(9):416-421.

Classen DC. (See Larsen RA).

Cleland JF. (See Goldwater PN).

Conrad SA. (See Crow S).

Corbett S. (See Wright JB).

Costerton JW. (See Wright JB).

Courtright P. (See Koo D).

Craig W. (See Silver HJ).

Credé WB, Hierholzer WJ Jr. Utilization Review and Management: A Brief A nalysis of a Growth Industry (Topics in Clinical Epidemiology). 10(1):33-36. Hierholzer WJ Jr. Analytic Strategies in Hospital Epidemiology: Cross-Sectional Studies (Topics in Clinical Epidemiology). 10(7):321-325.

Hierholzer WJ Jr. Surveillance for Quality Assess. ment: I. Surveillance in Infection Control Success Reviewed (Topics in Clinical Epidemiology). $10(10): 470-474$.

Cronin WA, Gröschel HM. A No-Rinse Alcohol Antiseptic and a No-Touch Dispenser for Hand Contamination (Product Commentary). 10(2):80-83.

Crow S. (See McDonald LL).

Washer-Decontaminator-An Evaluation (Product Commentary). 10(5):220-221.

Conrad SA, Chaney-Rowell C, King JW. Microbial Contamination of Arterial Infusions Used for Hemodynamic Monitoring: A Randomized Trial of Contamination with Sampling Through Conventional Stopcocks versus a N ovel Closed System. 10(12):557-561.

Cummings KM. (See Klimowski LL). (See Dash GP).

Cunha BA. (See Klein NC).

Currier RW. (See Silver HJ).

Cusick JL. (See Raad II).

Daschner FD. Infectious Waste Management: Will Science, Common Sense and Cost-Benefit Prevail? (Letter to the Editor). 10(10):440-441.

Dash GP, Rotstein C, Klimowski LL, Cummings KM. Aspergillosis Results Questioned (Letter to the Editor). 10(12):539-540.

Donowitz LG. (See Getchell-White SI). 
Turner RB, Searcy MAM, Luban NLC, Hendley JO. The High Rate of Blood Donor Exposure for Critically III Neonates. 10(11):509-510.

Eckert DG. (See Ehrenkranz NJ).

Ehrenkranz NJ, Alfonso BC, Moskowitz LB. Proteeae Groin Skin Carriage Among Nursing Home Residents-Resistance to Antiseptics. 10(4): 155-160.

Ehrenkranz NJ, Alfonso BC. Indications for Alcohol or Bland Soap in Removal of Aerobic GramNegative Skin Bacteria: Assessment by a Novel Method. 10(7):306-311.

Edmiston CE, Schmitt DD, Seabrook GR. CoagulaseNegative Staphylococcal Infections in Vascular Surgery: Epidemiology and Pathogenesis. 10(3):111-117.

Edmonds J. (See Ford-Jones EL).

Ehrenkranz NJ, Eckert DG, Alfonso BC, Moskowit LB. Proteeae Groin Skin Carriage in Ambulatory Geriatric Outpatients. 10(4):150-154.

(See Eckert DG).

Evans S. (See Larsen RA).

Farr BJ. (See Miller PJ).

Fauerbach LL. (See Raad II).

Ferguson J. (See Simmons BP).

Ford-Jones EL, Mindorff CM, Gold R. Satellite Infection Control Committees Within the Hospital: Decentralizing for Action (Readers' Forum). $10(8): 368-370$.

Mindorff CM, Pollock E, Milner R, Bohn D, Edmonds J, Barker G, Gold R. Evaluation of a New Method of Detection of N osocomial Infection in the Pediatric Intensive Care Unit: The Infection Control Sentinel Sheet System. 10(11):515-520.

Fuortes L, Melson E. Primary and Recurrent Herpes Simplex Infection in a Pediatric Nurse Resulting from a Human Bite (Brief Report). 10(3):120.

Gardner RM. (See Larsen RA).

Garibaldi RA, Wenzel RP. Challenges and Controversies (Editorial). 10(6):239-240.

Gelfand MS. Candida tropicalis (Topics in Clinical Microbiology). 10(6)280-283.

(See Simmons BP).

Getchell JP. (See Hausler WJ Jr.).

Getchell-White SI, Donowitz LG, Gröschel DHM. The Inanimate Environment of an Intensive Care Unit as a Potential Source of N osocomial Bacteria: Evidence for Long Survival of Acinetobacter calcoaceticus. 10(9):402-407.

Gibbs FB. Ceiling Maintenance-Why? (Letter to the Editor). 10(10):441-442.

Goetz A, Muder RR. Pseudomonas aeruginosa Infections Associated with Use of Povidonelodine in Patients Receiving Continous Ambulatory Peritoneal Dialysis. 10(10):447-450.

Gold R. Shigellosis in the Nursery (Editorial). 10(4): 145-146.

(See Ford-Jones EL).

Goldmann DA, Zuck TF. AIDS: Understanding the Pathogenesis of HIV Infection ( $\mathrm{New}$ Challenges and Controversies). 10(6):248-252.

Goldwater PN, Law R, Nixon AD, Officer JA, Cleland JF. Impact of a Recapping Device on Venepuncture-Related Needlestick Injury. 10(1):21-25.

Gorse GJ, M essner RL, Stephens ND. Association of Malnutrition with Nosocomial Infection. 10(5):194-203.

Gröschel DHM. (See Cronin WA).

(See Getchell-White SI).

Gross PA. Expanding Roles of Hospital Epidemiology: Severity of Illness Indicators (N ew Challenges and Controversies). 10(6):257-260.

Haas M. (See Simmons BP).

Haley CE, McDonald RC, Rossi L, Jones WD, Haley RW, Luby JP. Tuberculosis Epidemic Among Hospital Personnel. 10(5):204-210.

Haley RW. (See Haley CE).

Hamill RJ, Wright CE, A ndres N, Koza MA. Urinary Tract Infection Following Instrumentation for Urodynamic Testing. 10(I):26-32.

Hamory BH. (See Rutala WA).

Hancock G. (See Thomas JC).

Hannon WH, Lewis S, Jones WK, Powell MK. A Quality Assurance Program for Human Immunodeficiency Virus Seropositivity Screening of DriedBlood Spot Specimens. 10(1):8-13.

Hausler WJ Jr. Introduction: Status of Human Retrovirus Testing in State and Territorial Public Health Laboratories: Summary of Survey No. 6 (Fourth Consensus Conference on HIV Testing). 10(8):345-349.

Getchell JP. Report of the Fourth Consensus Conference on HIV Testing Sponsored by the Association of State and Territorial Public Health Laboratory Directors (ASTPHLD) (Fourth Consensus Conference on HIV Testing). 10(8):354-356.

Hebden JN. (See Martin MA).

Hendley JO. (See Donowit LG).

Heseltine PNR. (See Silver HJ).

Hibberd PL, Baker AS. Dangers of "Eye-to-Eye" Contact (Editorial). 10(3):99-101.

Hierholzer WJ Jr. (See Credé).

Himelright I. (See Sinnott JT).

Hodan C. (See Mylotte JM).

Hoffmann KK. Hospital Infection Control Principles and Practice; Second Edition; Mary Castle (Book Review). $10(10): 485-486$.

Weber DJ, Rutala WA. Pseudoepidemic of Rhodotorula rubra in Patients Undergoing Fiberoptic Bronchoscopy. 10(11):511-514.

Horsburgh CR Jr., A nderson JR, Boyko EF. Increased Incidence of Infections in Intravenous Drug Users. 10(5):211-215.

Horton P. (See Rose RC).

Hosobuchi K. (See Kobayashi H).

Howell N. (See Raad II).

Jarvis WR. (See Beck-Sague).

Jones WD. (See Haley CE).

Jones WK. (See Hannon WH).

Kates SG. (See Leyden J). 
Kedzia WB. Nosocomial Infections in Hospitals in Poznan, Poland (Readers' Forum). 10(2):74-76.

Kilman L. (See Thomas JC).

King JW. (See Crow S).

Klein NC, Schoch PE, Cunha BA. Nosocomial Group B Streptococcal Infections (Topics in Clinical Microbiology). 10(10):475-479.

Klimowski LL, Rotstein C, Cummings KM. Incidence of Nosocomial A spergillosis in Patients with Leukemia Over a Twenty-Year Period. 10(7):299-305.

(See Dash GP).

Kobayashi H, Tsuzuki M, Hosobuchi K. Bactericidal Effects of Antiseptics and Disinfectants Against Methicillin-Resistant Staphylococcus aureus (Brief Report). 10(12):562-564.

Koo D, Bouvier B, Wesley M, Courtright P, Reingold A. Epidemic Keratoconjunctivitis in a University Medical Center Ophthalmology Clinic-Need for Re-evaluation of the Design and Disinfection of Instruments. 10(12):547-552.

Koransky IH. Infectious Waste Management (Letter to the Editor). 10(5):191.

Maki DG, McGowan JE. Questions Raised About June Issue (Letter to the Editor). 10(11):500-502.

Koza MA. (See Hamill RJ).

Kunin CM. The Future of Hospital Epidemiology ( $N$ ew Challenges and Controversies). 10(6):276-279.

Lachenbruch PA. On Using Microcomputers in Statistical Analysis (Statistics for Hospital Epidemiology). 10(9):422-426.

Larsen RA, Evans S, Burke JP, Pestotnik S, Gardner RM, Classen DC. Improved Perioperative Antibiotic Use and Reduced Surgical Wound Infections Through Use of Computer Decision Analysis. 10(7):316-320.

Larson E. (See Bruch MK).

Law R. (See Goldwater PN).

Leyden JJ, McGinley KJ, Kates SG, Myung KB. Subungual Bacteria of the $\mathrm{H}$ and: Contribution to the Glove Juice Test; Efficacy of Antimicrobial Detergents. 10(10):451-454.

Levy CS, Nottebart HC. Infection Control Information and Malpractice Cases (Letter to the Editor). 10(7):295.

Levy J. Enteral Nutrition: An Increasingly Recognized Cause of N osocomial Bloodstream Infection (Editorial). 10(9):395-397.

Lewis S. (See Hannon WH).

Linnemann CC Jr. (See Moore PJ).

Luban NLC. (See Donowitz LG).

Luby JR (See Haley CE).

Mack L. (See Wormser GP).

Maki DG. (See Mermal LA)

AIDS: Serologic Testing for the Human Immunodeficiency Virus-To Screen or Not to Screen ( $\mathrm{N}$ ew Challenges and Controversies). $10(6): 243-247$.

(See Koransky IH).
Manasse R. (See Stone J).

Martin DB. (See Beers LM).

Martin MA, Hebden JN. Blood Culture Collection and Needle Punctures in Healthcare Workers (Letter to the Editor). 10(9):390-391.

McDermott C. (See Mylotte JM).

McDonald LL, Crow S. How Simple Is Disease-Specific Isolation? (Letter to the Editor). 10(4): 142-144.

McDonald RC. (See Haley CE).

McGinley KJ. (See Leyden JJ).

McGowan JE. Infection Control: New Problem Organisms for Infection Control (New Challenges and Controversies). 10(6):267-269.

(See Koransky IH).

McNutt LA. (See Woolson).

Medure-Collins R. (See Wormser GP).

Melson E. (See Fuortes L).

Mermal LA, Maki DG. Epidemic Bloodstream Infections From Hemodynamic Pressure Monitoring: Signs of the Times (Editorial). 10(2):47-53.

Mertens R. (See Reybrouck G).

Messner RL. (See Gorse GJ).

Metts L. (See Simmons BP).

Miller JM. Diamidine Use in Treatment of Pneumocystis carinii (Letter to the Editor). 10(8):344.

Miller PJ, Farr BM. Morbidity and Mortality Associated with Multiple Episodes of Nosocomial Bloodstream Infection: A Cohort Study. 10(5):216-219.

Milner R. (See Ford-Jones EL).

Mindorff CM. (See Ford-Jones EL).

Moncada D. (See Zaidi M).

Moore PJ, Linnemann CC Jr, Sanitato JJ, Binnion B. Pneumococcal Endophthalmitis after Corneal Transplantation: Control by Modification of Harvesting Techniques. 10(3):102-105.

Moraleda MH, Bolyard E. Calculating Infection Control Rates (Letter to the Editor). 10(9):389-390.

Moskowitz LB. (See Ehrenkranz NJ). (See Eckert DG).

Muder RR. (See Goetz A).

Murdock B. (See Platt R).

Mylotte JM, White D, McDermott C, Hodan C. Nosocomial Bloodstream Infection at a Veterans Hospital; 1979-1987. 10(10):455-464.

Myung KB. (See Leyden JJ).

Naides SJ. Infection Control Measures for Human Parvovirus B19 in the Hospital Setting (Readers' Forum). 10(7):326-330.

Nettleman MD. Game Theory: For Adults Only (Decision Analysis). 10(5):222-224.

Outcome Measurements in Decision Analysis: Life Versus Quality of Life (Decision Analysis). 10(11):521-524.

Nixon AD. (See Goldwater PN).

Nottebart HC. (See Levy CS).

Officer JA. (See Goldwater PN).

Pestotnik S. (See Larsen RA).

Pfaller MA. Infection Control: Opportunistic Fungal Infections-The Increasing Importance of Candida Species (New Challenges and Controversies). 
10(6):270-273.

(See Silver HJ).

Platt R, Polk F, Murdock B, Rosner B. Prevention of Catheter-Associated Urinary Tract Infection: A Cost-Benefit Analysis. 10(2): 60-64.

(See Burke JP).

Polk F. (See Platt R).

Pollock E. (See Ford-Jones EL).

Ponce de Leon S. (See Zaidi M).

Powell MK. (See Hannon WH).

Provencher M. (See Brown EA).

Raad II, Sherertz RI, Rains CS, Cusick JL, Fauerback LL, Reuman PD, Belcuore TR. The Importance of Nosocomial Transmission of Measles in the Propagation of a Community Outbreak. 10(4):161-166.

Cusick J, Sherertz RJ, Sabbagh M, Howell N. Annual Tuberculin Skin Testing of Employees at a University Hospital: A Cost-Benefit A nalysis. $10(10): 465-469$

Rains CS. (See Raad II)

Reingold A. (See Koo D).

Reuman PD. (See Raad II).

Reybrouck G, Mertens R. Infection Control and Hospital Hygiene in Belgium (Readers' Forum). $10(4): 170-174$.

Rhame FS. Aspergillosis: How Much Protection for Which Patients? (Editorial). 10(7):296-298.

Rickman LS. Herpes Simplex for a Human Bite (Letter to the Editor). 10(7):295.

Rose RC, Horton P. Response to Surgeon-Specific Infection Rates (Letter to the Editor). 10(4):142.

Rossi L. (See Haley CE).

Rosner B. (See Platt R).

Rotstein C. (See Klimowski LL). (See Dash GP).

Ruseska I. (See Wright JB).

Rutala WA. (See Weber DJ).

Hamory BH. Expanding Roles of Hospital Epidemiology: Employee $\mathrm{H}$ ealth-Chemical Exposure in the Health Care Setting (New Challenges and Controversies). 10(6):261-266. (See Hoffmann KK).

Ryan P. Evaluation of Rigid Container Systems for Sterilization (Product Commentary). 10(11):525-526.

Sabbagh M. (See Raad II).

Sacks T. (See Simchen E).

Sanitato JJ. (See Moore PJ).

Schaffner W. AIDS: Risk of HIV Infection to Health Care Workers (New Challenges and Controversies). $10(6): 241-242$.

Scheld WM. (SeeTunkel AR).

Schmitt DD. (See Edmiston CE).

Schoch PE. (See Klein NC).

Scrimshaw NS. Malnutrition and Nosocomial Infection (Editorial). 10(5):192-193.

Seabrook GR. (See Edmiston CE).

Searcy MAM. (See Donowitz LG).

Shapiro ED. Analytic Strategies in Hospital Epidemiology: Case-Control Studies (Topics in Clinical Epidemiology). 10(4):167-169.
Shapiro M. (See Simchen E).

Sherertz RJ. (See Raad II).

Sifuentes J. (See Zaidi M).

Silver HJ, Heseltine PNR. Oxacillin-Resistant S aureus (Letter to the Editor). 10(3):98.

Craig W. Are Draconian Measures Necessary When Using Multidose Vials? (Letter to the Editor). 10(5):190-191.

Currier RW, Trock SC. Salmonella. enteritidis in Eggs (Letter to the Editor). 10(8):343-344.

Pfaller MA. Reporting Sensitivity and Resistance of Bacteria to Antibiotics (Letter to the Editor). 10(9):389.

Simchen E, Wax Y, Shapiro M, Sacks T. Prospective Multihospital Surveillance Studies-A Controversy (Letter to the Editor). 10(3):94-98.

Simmons BP, Gelfand MS, Haas M, Metts L, Ferguson J. Enterobacter sakazakii Infections in Neonates A ssociated with Intrinsic Contamination of a Powdered Infant Formula. 10(9):398-401.

Sinnott JT, Himelright 1. Chlumydia Species Strain TWAR (Topics in Clinical Microbiology). 10(4):175-177.

Stapleton JT. HIV Transmission, Healthcare Workers and Media Hype (Editorial). 10(11):503-504.

Stephens ND. (See Gorse GJ).

Stone J, Manasse R. Pseudoepidemic of Urinary Tract Infections due to Trichosporon beigelii. 10(7):312-315.

Stratton CW. New Insights on the Genetic Basis for Resistance (Topics in Clinical Microbiology). 10(8):371-375.

Talbot G. (See Brown EA).

Tilson HH. (See Burke JP).

Thomas JC, Bridge J, Waterman S, Vogt J, Kilman L, Hancock G. Transmission and Control of Methicillin-Resistant Staphylococcus aureus in a Skilled Nursing Facility. 10(3):106-110.

Trock SC. (See Silver HJ).

Tunkel AR, Scheld WM. Therapy of Bacterial Meningitis: Principles and Practice (Clinical Pharmacology of Antibiotics). 10(12):565-569.

Turner RB. (See Donowitz LG).

Tsuzuki M. (See Kobayashi H).

Washington JA. Evaluation of New In Vitro Diagnostic Test Procedures in Clinical Microbiology (Topics in Clinical Microbiology). 10(2):77-79.

Waterman SH. (See Berlinberg CD). (See Thomas JC).

Wax Y. (See Simchen E).

Weber DJ, Rutala WA. Management of HIV-1 Infection in the Hospital Setting (Editorial). 10(1):3-7. (See Hoffmann KK)

Rutala, WA. Hepatitis B Immunization Update (Editorial). 10(12):541-546.

Weingarten SR. (See Berlinberg CD).

Wenzel Rl? (See Garibaldi RA).

Expanding Roles of Hospital Epidemiology: Quality Assurance (New Challenges and Controversies). 10(6):255-256.

Wesley M. (See Koo D). 
White D. (See Mylotte JM).

Woolson RF, McNutt LA. A nalysis of M atched Samples (Statistics for Hospital Epidemiology). 10(3): 123-126.

Wormser GP, Medure-Collins R, Mack L. Blood Contamination of Medical Records (Brief Report). 10(3):118-119.

Wright CE. (See Hamill RJ).

Wright JB, Ruseska I, A thar MA, Corbett S, Costerton JW. Legionella pneumophila Grows Adherent to Surfaces in vitro and in situ. 10(9):408-415.

Vogt J. (See Thomas JC).

Yangco BG, Yangco NE A Study of the Integrity of Hospital Gloves. 10(12):553-556.

Yangco NF. (See Yangco BG).

Young LS. Infection Control: The Immunocompromised Host (New Challenges and Controversies). 10(6):274-275.

Zaidi M, Sifuentes J, Bobadilla M, M oncada D, Ponce de Leon S. Epidemic of Serratia marcescens Bacteremia and Meningitis in a Neonatal Unit in Mexico City. 10(I):14-20.

Zuck TF. (See Goldmann DA).

Zygmunt DJ. Cryptosporidium species (Topics in Clinical Microbiology). 10(12):570-572.

\section{Subjects}

ACINE TOBACTER

Getchell-White SI, Donowitz LG, Gröschel DHM. The Inanimate Environment of an Intensive Care Unit as a Potential Source of N osocomial Bacteria: Evidence for Long Survival of Acinetobacter calcoaceticus. 10(9):402-40

ACQUIRED IMMUNODEFICIENCY SYNDROME (AIDS)

Goldmann DA, Zuck TF. AIDS: Understanding the Pathogenesis of HIV Infection (New Challenges and Controversies). 10(6):248-252

Hannon WH, Lewis S, Jones WK, Powell MK. A Quality Assurance Program for Human Immunodeficiency Virus Seropositivity Screening of DriedBlood Spot Specimens. 10(1):8-13.

Hausler WJ Jr. Introduction: Status of Human Retrovirus Testing in State and Territorial Public Health Laboratories: Summary of Survey No. 6 (Fourth Consensus Conference on HIV Testing). $10(8): 345-349$.

Hausler WJ Jr., Getchell JP. Report of the Fourth Consensus Conference on HIV Testing Sponsored by the Association of State and Territorial Public Health Laboratory Directors (ASTPHLD) (Fourth Consensus Conference on HIV Testing). 10(8):354-35

Interpretation and Use of the Western Blot Assay for Serodiagnosis of Human Immunodeficiency Virus Type I Infections. 10(8):350-353.

Koransky IH, Maki DG, McGowan JE. Questions Raised About June Issue (Letter to the Editor). 10(11):500-502.

Maki DG. AIDS: Serologic Testing for the Human
Immunodeficiency Virus-To Screen or $\mathrm{N}$ ot to Screen (New Challenges and Controversies). $10(6): 243-247$.

Schaffner W. AIDS: Risk of HIV Infection to Health Care Workers (New Challenges and Controversies). 10(6):241-242.

Stapleton JT. HIV Transmission, Healthcare Workers and Media Hype (Editorial). 10(11):503-504.

Weber DJ, Rutala WA. Management of HIV-I Infection in the Hospital Setting (Editorial). 10(1):3-7.

ASPERGILLOSIS

Dash GP, Rotstein C, Klimowski LL, Cummings KM. Aspergillosis Results Questioned (Letter to the Editor). 10(12):539-540.

Klimowski LL, Rotstein C, Cummings KM. Incidence of Nosocomial A spergillosis in Patients with Leukemia Over a Twenty-Year Period. 10(7): 299-305.

Rhame FS. Aspergillosis: How Much Protection for Which Patients? (Editorial). 10(7):296-298.

\section{BLOOD CONTAMINATION}

Crow S, Conrad SA, Chaney-Rowell C, King JW. Microbial Contamination of Arterial Infusions Used for Hemodynamic Monitoring: A Randomized Trial of Contamination with Sampling Through Conventional Stopcocks versus a Novel Closed System. 10(12):557-561.

Wormser GP, Medure-Collins R, Mack L. Blood Contamination of Medical Records (Brief Report). 10(3):118-119.

\section{BLOODSTREAM INFECTION}

Beck\&ague CM, Jarvis WR. Epidemic Bloodstream Infections Associated with Pressure Transducers: A Persistent Problem. 10(2):54-59.

Donowitz LG, Turner RB, Searcy MAM, Luban NLC, Hendley JO. The High Rate of Blood Donor Exposure for Critically 111 Neonates. 10(11): 509-510.

Levy J. Enteral Nutrition: An Increasingly Recognized Cause of Nosocomial Bloodstream Infection (Editorial) 10(9):395-397.

Mermal LA, Maki DG. Epidemic Bloodstream Infections From Hemodynamic Pressure Monitoring: Signs of the Times (Editorial). 10(2):47-53.

Miller PJ, Farr BM. Morbidity and Mortality Associated with Multiple Episodes of N osocomial Bloodstream Infection: A Cohort Study. 10(5):216-219.

Mylotte JM, White D, McDermott C, Hodan C. Nosocomial Bloodstream Infection at a Veterans Hospital; 1979-1987. 10(10)455-464.

\section{BOOK REVIEWS}

Bryan CS. Asepsis, the Right Touch. Something Old is Now New; Sue Crow (Book Review). 10(10):486.

Hoffman KK. Hospital Infection Control Principles and Practice; Second Edition; Mary Castle (Book Review). 10(10):485-486.

BRIEF REPORTS

Fuortes L, Melson E. Primary and Recurrent Herpes 
Simplex Infection in a Pediatric Nurse Resulting from a Human Bite (Brief Report). 10(3):120.

Kobayashi H, Tsuzuki M, Hosobuchi K. Bactericidal Effects of Antiseptics and Disinfectants Against Methicillin-Resistant Staphylococcus aureus (Brief Report). 10(12):562-564.

Wormser GP, Medure-Collins R, Mack L. Blood Contamination of Medical Records (Brief Report). 10(3):118-119.

\section{CANDIDA}

Pfaller MA. Infection Control: Opportunistic Fungal Infections-The Increasing Importance of $\mathrm{Can}$ dida Species (New Challenges and Controversies). 10(6):270-273.

Gelfand MS. Candida tropicalis (Topics in Clinical Microbiology). 10(6):280-283.

C H L A M Y D IA

Sinnott JT, Himelright I. Chlamydia Species Strain TWAR (Topics in Clinical Microbiology). 10(4):175-177.

\section{CLINICAL PHARMACOLOGY}

OF ANTIBIOTICS

Tunkel AR, Scheld WM. Therapy of Bacterial Meningitis: Principles and Practice (Clinical Pharmacology of Antibiotics). 10(12):565-569.

\section{DECISION ANALYSIS}

Larsen RA, Evans S, Burke JP, Pestotnik S, Gardner RM, Classen DC. Improved Perioperative Antibiotic Use and Reduced Surgical Wound Infections Through Use of Computer Decision Analysis. $10(7): 316-320$.

Nettleman MD. Game Theory: For Adults Only (Decision A nalysis). 10(5):222-224.

Nettleman MD. Outcome Measurements in Decision Analysis: Life Versus Quality of Life (Decision Analysis). 10(11):521-524.

\section{EDITORIALS}

Anderson RL. Iodophor Antiseptics: Intrinsic Microbial Contamination with Resistant Bacteria (Editorial). 10(10):443-446.

Garibaldi RA, Wenzel RP. Challenges and Controversies (Editorial). 10(6):239-240.

Gold R. Shigellosis in the Nursery (Editorial). 10(4):145-146.

Hibberd PL, Baker AS. Dangers of "Eyeto-Eye" Contact (Editorial). 10(3):99-101.

Levy J. Enteral Nutrition: An Increasingly Recognized Cause of Nosocomial Bloodstream Infection (Editorial). 10(9):395-397.

Mermal LA, Maki DG. Epidemic Bloodstream Infections From Hemodynamic Pressure Monitoring: Signs of the Times (Editorial). 10(2):47-53.

Rhame FS. Aspergillosis: How Much Protection for Which Patients? (Editorial). 10(7):296-298.

Scrimshaw NS. Malnutrition and N osocomial Infection (Editorial). 10(5):192-193.

Stapleton JT. HIV Transmission, Healthcare Workers and Media Hype (Editorial). 10(11):503-504.
Weber DJ, Rutala WA. Management of HIV-I Infection in the Hospital Setting (Editorial). 10(I):3-7.

Weber DJ, Rutala WA. Hepatitis B Immunization Update (Editorial). 10(12):541-546.

ENTEROB A CTER

Simmons BP, Gelfand MS, Haas M, Metts L, Ferguson J. Enterobacter sakazakii Infections in Neonates Associated with Intrinsic Contamination of a Powdered Infant Formula. 10(9):398-401.

\section{FDA REGULATIONS}

Bruch MK, Larson E. An Early Historical Perspective on the FDA's Regulation of OTC Drugs (Readers' Forum). 10(11):527-528.

Bruch MK, Larson E. Regulation of Topical Antimicrobials: History, Status and Future Perspective. 10(11):505-508.

\section{FOURTH CONSENSUS CONFERENCE ON HIV} TESTING

Consensus Recommendations. 10(8):358-367.

Hausler WJ Jr. Introduction: Status of Human Retrovirus Testing in State and Territorial Public Health Laboratories: Summary of Survey No. 6 (Fourth Consensus Conference on HIV Testing). 10(8):345-349.

Hausler WJ Jr., Getchell JP. Report of the Fourth Consensus Conference on HIV Testing Sponsored by the Association of State and Territorial Public Health Laboratory Directors (ASTPHLD) (Fourth Consensus Conference on HIV Testing). 10(8):354-35

Instructions to Workgroups. 10(8):357.

Interpretation and Use of the Western Blot A ssay for Serodiagnosis of Human Immunodeficiency Virus Type I Infections. 10(8):350-353.

\section{GERIATRIC PATIENTS/INFECTION CONTROL}

Bentley DW. Current Challenges and Future Opportunities (Topics in Long-Term Care). 10(10): 481-483.

Eckert DG, Ehrenkranz NJ, Alfonso BC, Moskowitz LB. Proteeae Groin Skin Carriage Among N ursing Home Residents-Resistance to Antiseptics. 10(4):155-160.

Ehrenkranz NJ, Eckert DG, Alfonso BC, Moskowitz LB. Proteeae Groin Skin Carriage in Ambulatory Geriatric Outpatients. 10(4): 150-154.

\section{HANDWASHING}

Cronin WA, Gröschel HM. A No-Rinse Alcohol Antiseptic and a No-Touch Dispenser for Hand Contamination (Product Commentary). 10(2):80-83.

Eckert DG, Ehrenkranz NJ, Alfonso BC. Indications for Alcohol or Bland Soap in Removal of Aerobic Gram-Negative Skin Bacteria: Assessment by a Novel Method. 10(7):306-311.

Leyden JJ, McGinley KJ, Kates SG, Myung KB. Subungual Bacteria of the Hand: Contribution to the Glove Juice Test; Efficacy of Antimicrobial Detergents. 10(10):451-454. 


\section{HEALTHCARE WORKER SAFETY}

Berlinberg CD, Weingarten SF, Bolton LB, Waterman SH. Occupational Exposure to InfluenzaIntroduction of an Index Case to a Hospital. 10(2):70-73.

Goldwater PN, Law R, Nixon AD, Officer JA, Cleland JF. Impact of a Recapping Device on Venepuncture-Related Needlestick Injury. 10(1):21-25.

Haley CE, M cDonald RC, Rossi L, Jones WD, Haley RW, Luby JP. Tuberculosis Epidemic Among Hospital Personnel. 10(5):204-210.

Martin MA, Hebden JN. Blood Culture Collection and Needle Punctures in Healthcare Workers (Letter to the Editor). 10(9):390-391.

Raad II, Cusick J, Sherert RJ, Sabbagh M, Howell N. A nnual Tuberculin Skin Testing of Employees at a University Hospital: A Cost-Benefit Analysis. 10(10):465-469.

Rutala WA, Hamory BH. Expanding Roles of Hospital Epidemiology: Employee Health-Chemical Exposure in the Health Care Setting (New Challenges and Controversies). 10(6):261-266.

Stapleton JT. HIV Transmission, Healthcare Workers and Media Hype (Editorial). 10(11):503-504.

Yangco BG, Yangco NE A Study of the Integrity of Hospital Gloves. 10(12):553-556.

\section{HEPATITIS}

Weber DJ, Rutala WA. Hepatitis B Immunization Update (Editorial). 10(12):541-546.

\section{HERPES}

Fuortes L, Melson E. Primary and Recurrent Herpes Simplex Infection in a Pediatric Nurse Resulting from a Human Bite (Brief Report). 10(3):120.

Rickman LS. Herpes Simplex for a H uman Bite (Letter to the Editor). 10(7):295.

\section{HOSPITAL EPIDEMIOLOGY}

Burke JP, Tilson HH, Platt R. Expanding Roles of Hospital Epidemiology: Pharmacoepidemiology (New Challenges and Controversies). 10(6): 253-254.

Crow S, Conrad SA, Chaney-Rowell C, King JW. Microbial Contamination of Arterial Infusions Used for Hemodynamic Monitoring: A Randomized Trial of Contamination with Sampling Through Conventional Stopcocks versus a Novel Closed System. 10(12):557-561.

Ford-Jones EL, Mindorff CM, Gold R. Satellite Infection Control Committees Within the Hospital: Decentralizing for Action (Readers' Forum). 10(8):368-370.

Ford-Jones EL, Mindorff CM, Pollock E, Milner R, Bohn D, Edmonds J, Barker G, Gold R. Evaluation of a New Method of Detection of Nosocomial Infection in the Pediatric Intensive Care Unit: The Infection Control Sentinel Sheet System. $10(11): 515-520$.

Goetz A, Muder RR. Pseudomonas aeruginosa Infections Associated with Use of Povidone-lodine in Patients Receiving Continous Ambulatory Peri- toneal Dialysis. 10(10):515-520.

Gross PA. Expanding Roles of Hospital Epidemiology: Severity of IIIness Indicators (N ew Challenges and Controversies). 10(6):257-260.

Kunin CM. The Future of Hospital Epidemiology (New Challenges and Controversies). 10(6): 276-279.

Shapiro ED. Analytic Strategies in Hospital Epidemiology: Case-Control Studies (Topics in Clinical Epidemiology). 10(4):167-169.

Silver HJ, Pfaller MA. Reporting Sensitivity and Resistance of Bacteria to Antibiotics (Letter to the Editor). 10(9):389.

HUMAN IMMUNODEFICIENCY VIRUS (HIV)

See Acquired Immunodeficiency Syndrome (AIDS)

\section{IMMUNOCOMPROMISED PATIENTS}

Brown EA, Tal bot GH, Provencher $M$, Cassileth P. A naerobic Bacteremia in Patients with Acute Leukemia. 10(2):65-69.

Klimowski LL, Rotstein C, Cummings KM. Incidence of N osocomial Aspergillosis in Patients with Leukemia over a Twenty-Year Period. 10(7):299305.

Rhame FS. Aspergillosis: How Much Protection for Which Patients? (Editorial). 10(7):296-298.

Young LS. Infection Control: The Immunocompromised Host (N ew Challenges and Controversies). $10(6): 274-275$.

INFECTION CONTROL OUTSIDE THE U.S.

Campbell B. Infection Control in Canada (Readers' Forum). 10(3):121-122.

Kedzia WB. Nosocomial Infections in Hospitals in Poznan, Poland (Readers' Forum). 10(2):74-76.

Reybrouck G, Mertens R. Infection Control and Hospital Hygiene in Belgium (Readers' Forum). 10(4):170-174.

Zaidi M, Sifuentes J, Bobadilla M, M oncada D, Ponce de Leon S. Epidemic of Serratia marcescens Bacteremia and Meningitis in a N eonatal Unit in Mexico City. 10(l): 14-20.

\section{INFECTION RATES}

Moraleda MH, Bolyard E. Calculating Infection Control Rates (Letter to the Editor). 10(9):389-390.

Rose RC, Horton P. Response to Surgeon-Specific Infection Rates (Letter to the Editor). 10(4):142.

\section{INFECTIOUS WASTE MANAGEMENT}

Daschner FD. Infectious Waste Management: Will Science, Common Sense and Cost-Benefit Prevail? (Letter to the Editor). 10(10):440-441.

Koransky IH. Infectious Waste Management (Letter to the Editor). 10(5):191.

\section{INFLUENZA}

Berlinberg CD, Weingarten SF, Bolton LB, Waterman SH. Occupational Exposure to InfluenzaIntroduction of an Index Case to a Hospital. $10(2): 70-73$. 
INTRAVENOUS DRUG USERS

Horsburgh CR Jr., A nderson JR, Boyko EF. Increased Incidence of Infections in Intravenous Drug Users. 10(5):211-215.

\section{ISOLATION}

McDonald LL, Crow S. H ow Simple is Disease-Specific Isolation! (Letter to the Editor). 10(4): 142-144.

\section{KERATOCONJUNCTIVITIS}

Koo D, Bouvier B, Wesley M, Courtright P, Reingold A. Epidemic Keratoconjunctivitis in a University Medical Center Ophthalmology Clinic- Need for Re-evaluation of the Design and Disinfection of Instruments. 10(12):547-552.

LEGIONELLA

Wright JB, Ruseska I, Athar MA, Corbett S, Costerton JW. Legionella pneumophila Grows Adherent to Surfaces in vitro and in situ. 10(9):408-415.

\section{LETTERS TO THE EDITOR}

Birnbaum D. Cross-Sectional Survey Sampling (Letter to the Editor). 10(11):502.

Daschner FD. Infectious Waste Management: Will Science, Common Sense and Cost-Benefit Prevail? (Letter to the Editor). 10(10):440-441.

Dash GP, Rotstein C, Klimowski LL, Cummings KM. Aspergillosis Results Questioned (Letter to the Editor). 10(12):539-540.

Gibbs FB. Ceiling Maintenance-Why? (Letter to the Editor). 10(10):441-442.

Koransky IH. Infectious Waste Management (Letter to the Editor). 10(5):191.

Koransky IH, Maki DG, McGowan JE. Questions Raised About June Issue (Letter to the Editor). 10(11):500-502.

Martin MA, Hebden JN. Blood Culture Collection and Needle Punctures in Healthcare Workers (Letter to the Editor). 10(9):390-391.

McDonald LL, Crow S. How Simple is Disease-Specific Isolation? (Letter to the Editor). 10(4): 142-144.

Miller JM. Diamidine Use in Treatment of Pneumocystis carinii (Letter to the Editor). 10(8):344.

Moraleda MH, Bolyard E. Calculating Infection Control Rates (Letter to the Editor). 10(9):389-390.

Rickman LS. Herpes Simplex for a Human Bite (Letter to the Editor). 10(7):295.

Rose RC, Horton P. Response to Surgeon-Specific Infection Rates (Letter to the Editor). 10(4):142.

Silver HJ, Craig W. Are Draconian Measures Necessary When Using Multidose Vials? (Letter to the Editor). 10(5):190-191.

Silver HJ, Currier RW, Trock SC. Salmonella enteritidis in Eggs (Letter to the Editor). 10(8):343-344.

Silver HJ, Heseltine PNR. Oxacillin-Resistant $S$ aureus (Letter to the Editor). 10(3):98.

Silver HJ, Pfaller MA. Reporting Sensitivity and Resistance of Bacteria to Antibiotics (Letter to the Editor). 10(9):389.

Simchen E, Wax Y, Shapiro M, Sacks T. Prospective
Multihospital Surveillance Studies-A Controversy (Letter to the Editor). 10(3):94-98.

\section{MALNUTRITION}

Gorse GJ, M essner RL, Stephens ND. Association of Malnutrition with Nosocomial Infection. 10(5):194-203

Scrimshaw NS. Malnutrition and Nosocomial Infection (Editorial). 10(5):192- 193.

\section{MALPRACTICE}

Levy CS, Nottebart HC. Infection Control Information and Malpractice Cases (Letter to the Editor). 10(7):295.

\section{MEASLES}

Raad II, Sherertz RJ, Rains CS, Cusick JL, Fauerback LL, Reuman PD, Belcuore TR. The Importance of Nosocomial Transmission of Measles in the Propagation of a Community Outbreak. 10(4):161-166.

\section{MENINGITIS}

Tunkel AR, Scheld WM. Therapy of Bacterial Meningitis: Principles and Practice (Clinical Pharmacology of Antibiotics). 10(12):565-569.

Zaidi M, Sifuentes J, Bobadilla M, M oncada D, Ponce de Leon S. Epidemic of Serratia marcescens Bacteremia and Meningitis in a Neonatal Unit in Mexico City. 10(l):14-20.

\section{METHICILLIN-RESISTANT} A URE US

Kobayashi H, Tsuzuki M, Hosobuchi K. Brief Report: Bactericidal Effects of Antiseptics and Disinfectants Against Methicillin Resistant Staphylococcus aureus. 10( 12):

Thomas JC, Bridge J, Waterman S, Vogt J, Kilman L, Hancock G. Transmission and Control of Methicillin-Resistant Staphylococcus aureus in a Skilled Nursing Facility. 10(3):106-110.

\section{NEEDLESTICK INJURIES}

Goldwater PN, Law R, Nixon AD, Officer JA, Cleland JF. Impact of a Recapping Device on Venepuncture-Related Needlestick Injury. 10(l):21-25.

\section{NEONATAL INFECTION CONTROL}

Beers LM, Burke TL, Martin DB. Shigellosis Occurring in Newborn Nursery Staff. 10(4):147-149.

Donowitz LG, Turner RB, Searcy MAM, Luban NLC, Hendley JO. The High Rate of Blood Donor Exposure for Critically III Neonates. 10(11): 509-510.

Gold R. Shigellosis in the Nursery (Editorial). 10(4):145-146.

Levy J. Enteral Nutrition: An Increasingly Recognized Cause of Nosocomial Bloodstream Infection (Editorial). 10(9):395-397.

Simmons BP, Gelfand MS, Haas M, Metts L, Ferguson J. Enterobacter sakazakii Infections in $\mathrm{NeO}$ nates Associated with Intrinsic Contamination of a Powdered Infant Formula. 10(9):398-401.

Zaidi M, Sifuentes J, Bobadilla M, M oncada D, Ponce de Leon S. Epidemic of Serratia marcescens Bacteremia and Meningitis in a Neonatal Unit in Mex- 
ico City. 10(l): 14-20.

NEW DEVELOPMENTS IN INFECTION CONTROL

McGowan JE. Infection Control: New Problem Organisms for Infection Control (New Challenges and Controversies). 10(6):267-269.

Stratton CW. New Insights on the Genetic Basis for Resistance (Topics in Clinical Microbiology). $10(8): 371-375$.

Washington JA. Evaluation of New In Vitro Diagnostic Test Procedures in Clinical Microbiology (Topics in Clinical Microbiology). 10(2)77-79.

\section{NOSOCOMIAL INFECTION}

Anderson RL. Iodophor Antiseptics: Intrinsic Microbial Contamination with Resistant Bacteria (Editorial). 10(10):443-446.

Getchell-White SI, Donowitz LG, Groschel DHM. The Inanimate Environment of an Intensive Care Unit as a Potential Source of N osocomial Bacteria: Evidence for Long Survival of Acinetobacter calcoaceticus. 10(9):402-407.

Gorse G, Messner RL, Stephens ND. Association of Malnutrition with Nosocomial Infection. 10(5): 194-203.

Hoffmann KK, Weber DJ, Rutala WA. Pseudoepidemic of Rhodotorula rubra in Patients Undergoing Fiberoptic Bronchoscopy. 10(11):511-514.

Kedzia WB. Nosocomial Infections in Hospitals in Poznan, Poland (Readers' Forum). 10(2):74-76.

Klein NC, Schoch PE, Cunha BA. Nosocomial Group B Streptococcal Infections (Topics in Clinical Microbiology). 10(10):472-479.

Klimowski LL, Rotstein C, Cummings KM. Incidence of Nosocomial A spergillosis in Patients with Leukemia over a Twenty-Year Period. 10(7):299305.

Miller PJ, Farr BM . Morbidity and Mortality Associated with Multiple Episodes of N osocomial Bloodstream Infection: A Cohort Study. 10(5):216-219.

Mylotte JM, White D, McDermott C, Hodan C. Nosocomial Bloodstream Infection at a Veterans Hospital; 1979-1987. 10(10):455-464.

Raad II, Sherertz RJ, Rains CS, Cusick JL, Fauerback LL, Reuman PD, Belcuore TR. The Importance of Nosocomial Transmission of Measles in the Propagation of a Community Outbreak. 10(4):161-166.

Scrimshaw NS. Malnutrition and Nosocomial Infection (Editorial). 10(5):192-193.

\section{OPTICAL INFECTION}

Hibberd PL, Baker AS. Dangers of "Eye-to-Eye" Contact (Editorial). 10(3):99-101.

Koo D, Bouvier B, Wesley M, Courtright P, Reingold A. Epidemic Keratoconjunctivitis in a University Medical Center Ophthalmology Clinic-Need for Re-evaluation of the Design and Disinfection of Instruments. 10(12):547-552.

Moore PJ, Linnemann CC Jr, Sanitato JJ, Binnion B. I'neumococcal Endophthalmitis after Corneal Transplantation: Control by Modification of Har- vesting Techniques. 10(3):102-105.

\section{PARVOVIRUS B19}

Naides SJ. Infection Control Measures for Human Parvovirus B19 in the Hospital Setting (Readers' Forum). 10(7):326-330.

\section{PEDIATRIC INFECTION CONTROL}

Getchell-White SI, Donowitz LG, Groschel DHM. The Inanimate Environment of an Intensive Care Unit as a Potential Source of N osocomial Bacteria: Evidence for Long Survival of Acinetobacter calcoaceticus. 10(9):402-407.

PNE UMOCYSTIS

Miller JM. Diamidine Use in Treatment of Pneumocystis carinii (Letter to the Editor). 10(8):344.

POVIDONE IODINE-ASSOCIATED INFECTIONS

Anderson RL. Iodophor Antiseptics: Intrinsic Microbial Contamination with Resistant Bacteria (Editorial). 10(10):443.

Goetz A, Muder RR. Pseudomonas aeruginosa Infections Associated with Use of Povidone-lodine in Patients Receiving Continuous Ambulatory Peritoneal Dialysis. 10(10):447-450.

\section{PRODUCT COMMENTARY}

Bryan CS. Surgeon-Specific Wound Surveillance: The Family or the Bean Counters? (Special Commentary). 10(8):376-378.

Cronin WA, Gröschel HM. A No-Rinse Alcohol Antiseptic and a No-Touch Dispenser for Hand Contamination (Product Commentary). 10(2):80-83.

Crow S. Washer-Decontaminator-An Evaluation (Product Commentary). 10(5):220-221.

Ryan P. Evaluation of Rigid Container Systems for Sterilization (Product Commentary). 10(11): 525-526.

PROTEUS

Eckert DG, Ehrenkranz NJ, Alfonso BC, Moskowitz LB. Proteeae Groin Skin Carriage A mong Nursing Home Residents-Resistance to Antiseptics. 10(4): 155-160.

Ehrenkranz NJ, Eckert DG, Alfonso BC, Moskowitz LB. Proteeae Groin Skin Carriage in Ambulatory Geriatric Outpatients. 10(4):150-154.

\section{PSEUDOEPIDEMICS}

Church DL, Bryant HE. Investigation of a Streptococcus viridans Pseudobacteremia Epidemic at a University Teaching Hospital. 10(9):416-421.

PSEUDOMONAS

Goetz A, Muder RR. Pseudomonas aeruginosa Infections Associated with Use of Povidone-lodine in Patients Receiving Continuous Ambulatory Peritoneal Dialysis. 10(10):447-450.

\section{QUALITY ASSURANCE}

Credé WB, Hierholzer WJ Jr. Surveillance for Quality Assessment: I. Surveillance in Infection 
Control Success Reviewed (Topics in Clinical Epidemiology). 10(10):470-474.

Ford-Jones EL, Mindorff CM, Gold R. Satellite Infection Control Committees Within the Hospital: Decentralizing for Action (Readers' Forum). 10(8):368-370.

Ford-Jones EL, Mindorff CM, Pollock E, Milner R, Bohn D, Edmonds J, Barker G, Gold R. Evaluation of a New Method of Detection of Nosocomial Infection in the Pediatric Intensive Care Unit: The Infection Control Sentinel Sheet System. 10(11):515-520.

Gibbs FB. Ceiling Maintenance-Why? (Letter to the Editor). 10(10):441-442.

Silver HJ, Craig W. Are Draconian Measures Necessary When Using Multidose Vials? (Letter to the Editor). 10(5):190-191.

Wenzel RP. Expanding Roles of Hospital Epidemiology: Quality Assurance ( $\mathrm{N}$ ew Challenges and Controversies). 10(6):255-256.

\section{READERS' FORUM}

Bruch MK, Larson E. An Early Historical Perspective on the FDA's Regulation of OTC Drugs (Readers Forum). 10(11):527-528.

Campbell B. Infection Control in Canada (Readers' Forum). 10(3):121-122.

Ford-Jones EL, Mindorff CM, Gold R. Satellite Infectin Control Committees Within the Hospital: Decentralizing for Action (Readers' Forum). $10(8): 368-370$.

Kedzia WB. Nosocomial Infections in Hospitals in Poznan, Poland (Readers' Forum). 10(2):74-76.

Naides SJ. Infection Control Measures for Human Parvovirus B19 in the Hospital Setting (Readers' Forum). 10(7):326-330.

Reybrouck G, Mertens R. Infection Control and Hospital Hygiene in Belgium (Readers' Forum). 10(4): 170-174.

\section{RHODOTOR ULA}

Hoffmann KK, Weber DJ, Rutala WA. Pseudoepidemic of Rhodotorula rubra in Patients Undergoing Fiberoptic Bronchoscopy. 10(11):511-514.

SALMONELLA

Silver HJ, Currier RW, Trock SC. Salmonella enteritidis in Eggs (Letter to the Editor). 10(8):343-344.

SERRATIA

Zaidi M, Sifuentes J, Bobadilla M, M oncada D, Ponce de Leon S. Epidemic of Serratia marcescens Bacteremia and Meningitis in a Neonatal Unit in Mexico City. 10(I):14-20.

\section{SHEA NEWSLETTER}

A nnual SHEA Luncheon/ Business Meeting. $10(6): 286$

Annual SHEA Meeting. 10(11):529.

ASM Division L Membership and SHEA Representation. $10(9): 427$.

British Hospital Infection Society International Conference. $10(5): 226$.
CDC Conference Announcement. 10(10):487.

Certification Examination Scheduled. 10(8):380.

Election Results. 10(10):529.

Final Call for Abstracts for SHEA/ICEHE National Meeting. 10(1):38.

Garibaldi RA. Whither Infection Control? 10(l):37.

Goldmann DA, Kaiser AB, Martone WJ. SHEA/CDC Hospital Epidemiology Course-A nother Hit. $10(5): 225$.

Hierholzer WJ Jr. A Message from the President. 10(2):87.

Hierholzer WJ Jr. President's End of Year Report. 10(12):577-578.

Hierholzer WJ Jr. President's Message. 10(7):331-332

Hospital Infection Director - CDC. 10(4):180.

IDSA Liaison Report. 10(3):136.

Infection Control Meeting - China. 10(4):180, $10(5): 226$.

Infection Control Standards-Joint Commission. $10(2): 88$.

J ob Market. $10(8): 380,10(9): 427,10(10): 488$, 10(12):578.

Liaison Report. 10(8):379.

Liaison Report - CDC. 10(1):38.

National Health Objectives. 10(11):530.

New Infection Control Standards. 10(9):427.

NFID Revises Research Priorities. 10(9):427.

Nominating Committee Appointed. 10(4):179.

Nosocomial Sessions at Upcoming ASM Meetings. $10(4): 180$.

OSHA Site Visits. 10(2):88.

Parvovirus B19 Infections. 10(5):226.

Reader Inquiry. 10(5):226.

SHEA Annual Luncheon and Open Meeting. $10(8): 380$.

SHEA Annual Luncheon Meeting. 10(3): 136.

SHEA Associates-The Cost-Effective Approach. $10(1): 38,10(2): 88,10(3): 136,10(5): 226$.

SHEA Board Meeting. 10(3):135, 10(11):530.

SHEA/CDC Training Program for Hospital Epidemiologists. 10(1):38,10(2):88, 10(12):587.

SHEA Cosponsors National Forum on AIDS/ Hepatitis B. $10(8): 379$.

SHEA Directory-Update. 10(3):136.

SHEA Elections. 10(8):380.

SHEA Information/ Membership. 10(6):285.

SHEA Luncheon Reminder. 10(9):427.

SHEA National Meeting a Hit. 10(4): 179.

SHEA Response to OSHA. 10(10):487.

Update on Joint Commission's Hospital-Wide/ Clinical Indicators Task Force. 10(1):38.

\section{SHIGELLOSIS}

Beers LM, Burke TL, Martin DB. Shigellosis Occurring in Newborn Nursery Staff 10(4):147-149.

Gold R. Shigellosis in the Nursery (Editorial). 10(4):145-146.

STAPHYLOCOCCUS

Edmiston CE, Schmitt, DD, Seabrook GR. Coagulase-Negative Staphylococcal Infections in Vas- 
cular Surgery: Epidemiology and Pathogenesis. 10(3):111-117.

Kobayashi H, Tsuzuki M, Hosobuchi K. Bactericidal Effects of Antiseptics and Disinfectants Against Methicillin-Resistant Staphylococcus aureus (Brief Report). 10(12):562-564.

Silver HJ, Heseltine PNR. Oxacillin-Resistant $S$ aureus (Letter to the Editor). 10(3):98.

Thomas JC, Bridge J, Waterman S, Vogt J, Kilman L, Hancock G. Transmission and Control of Methicillin-Resistant Staphylococcus aureus in a Skilled Nursing Facility. 10(3):106-110.

STATISTICS FOR HOSPITAL EPIDEMIOLOGY

Birnbaum D. Cross-Sectional Survey Sampling (Letter to the Editor). 10(11):502.

Burmeister LF. Cluster Sampling in Hospital Surveillance (Statistics for Hospital Epidemiology). 10(12):573-575.

Credé WB, Hierholzer WJ Jr. A nalytic Strategies in Hospital Epidemiology: Cross-Sectional Studies (Topics in Clinical Epidemiology). 10(7):321-325.

Lachenbruch PA. On Using Microcomputers in Sta tistical A nalysis (Statistics for Hospital Epidemiology). 10(9):422-426.

Woolson RF, McNutt LA. Analysis of M atched Samples (Statistics for Hospital Epidemiology). 10(3):123-126.

\section{STERILIZATION}

Crow S. Washer-Decontaminator-An Evaluation (Product Commentary). 10(5):220-221.

Koo D, Bouvier B, Wesley M, Courtright P, Reingold A. Epidemic Keratoconjunctivitis in a University Medical Center Ophthalmology Clinic - Need for Re-evaluation of the Design and Disinfection of Instruments. 10(12):547-552.

Ryan I?. Evaluation of Rigid Container Systems for Sterilization (Product Commentary). 10(11): 525-526.

\section{STRE PTOCOCCUS}

Church DL, Bryant HE. Investigation of a Streptococcus viridans Pseudobacteremia Epidemic at a University Teaching Hospital. 10(9):416-421.

Klein NC, Schoch PE, Cunha BA. Nosocomial Group B Streptococcal Infections (Topics in Clinical Microbiology). 10(10):475-479.

SURGICAL WOUND INFECTION

Bryan CS. Surgeon-Specific Wound Surveillance: The Family or the Bean Counters? (Special Commentary). 10(8):376-378.

Larsen RA, Evans S, Burke JP, Pestotnik S, Gardner RM, Classen DC. Improved Perioperative Antibiotic Use and Reduced Surgical Wound Infections Through Use of Computer Decision Analysis. 10(7):316-320.

\section{SURVEILLANCE}

Bryan CS. Surgeon-Specific Wound Surveillance: The Family or the Bean Counters? (Special Commentary). 10(8):376-378.
CredC WB, Hierholzer WJ Jr. Surveillance for Quality Assessment: I. Surveillance in Infection Control Success Reviewed (Topics in Clinical Epidemiology). 10(10):470-474.

Simchen E, Wax Y, Shapiro M, Sacks T. Prospective Multihospital Surveillance Studies-A Controversy (Letter to the Editor). 10(3):94-98.

\section{TOPICS IN CLINICAL EPIDEMIOLOGY}

CredC WB, Hierholzer WJ Jr. A nalytic Strategies in Hospital Epidemiology: Cross-Sectional Studies (Topics in Clinical Epidemiology). 10(7):321-325.

CredC WB, Hierholzer WJ Jr. Surveillance for Quality Assessment: I. Surveillance in Infection Control Success Reviewed (Topics in Clinical Epidemiology). 10(10):470-474.

CredC WB, Hierholzer WJ Jr. Utilization Review and Management: A Brief Analysis of a Growth Industry (Topics in Clinical Epidemiology). 10(1):33-36.

Shapiro ED. Analytic Strategies in Hospital Epidemiology: Case-Control Studies (Topics in Clinical Epidemiology). 10(4):167-169.

\section{TOPICS IN CLINICAL MICROBIOLOGY}

Gelfand MS. Candidu tropicalis (Topics in Clinical Microbiology). 10(6):280-283.

Klein NC, Schoch PE, Cunha BA. Nosocomial Group B Streptococcal Infections (Topics in Clinical Microbiology). 10(10):475-479.

Sinnott JT, Himelright 1. Chlamydia Species Strain TWAR (Topics in Clinical Microbiology). 10(4): 175-177.

Stratton CW. New Insights on the Genetic Basis for Resistance (Topics in Clinical Microbiology). 10(8):371-375.

Washington JA. Evaluation of New In Vitro Diagnostic Test Procedures in Clinical Microbiology (Topics in Clinical Microbiology). 10(2):77-79.

Zygmunt DJ. Cryptosporidium Species (Topics in Clinical Microbiology). 10(12):570-572.

TOPICS IN LONG-TERM CARE

Bentley DW. Current Challenges and Future Opportunities (Topics in Long- Term Care). 10(10): 481-483.

TRICHOSPORON

Stone J, Manasse R. Pseudoepidemic of Urinary Tract Infections due to Trichosporon beigelii. 10(7)312-315.

\section{TUBERCULOSIS}

Haley CE, Mcdonald RC, Rossi L, Jones WD, Haley RW, Luby JP. Tuberculosis Epidemic Among Hospital Personnel. 10(5):204-210.

Raad II, Cusick J, Sherertz RJ, Sabbagh M, Howell N. A nnual Tuberculin Skin Testing of Employees at a University Hospital: A Cost-Benefit Analysis. 10(10):465-469.

\section{URINARY TRACT INFECTIONS}

Hamill RJ, Wright CE, Andres N, Koza MA. Urinary Tract Infection Following Instrumentation for 
Urodynamic Testing. 10(I):26-32.

Platt R, Polk F, Murdock B, Rosner B. Prevention of Catheter-Associated Urinary Tract Infection: A Cost-Benefit Analysis. 10(2):60-64

Stone J, Manasse R. Pseudoepidemic of Urinary Tract Infections due to Trichosporon beigelii.
10(7):312-315.

VETERANS ADMINISTRATION

Mylotte JM, White D, M CDermott C, Hodan C. Nosocomial Bloodstream Infection at a Veterans Hospital; 1979-1987. 10(10):455-464.

This space contributed as a public service.

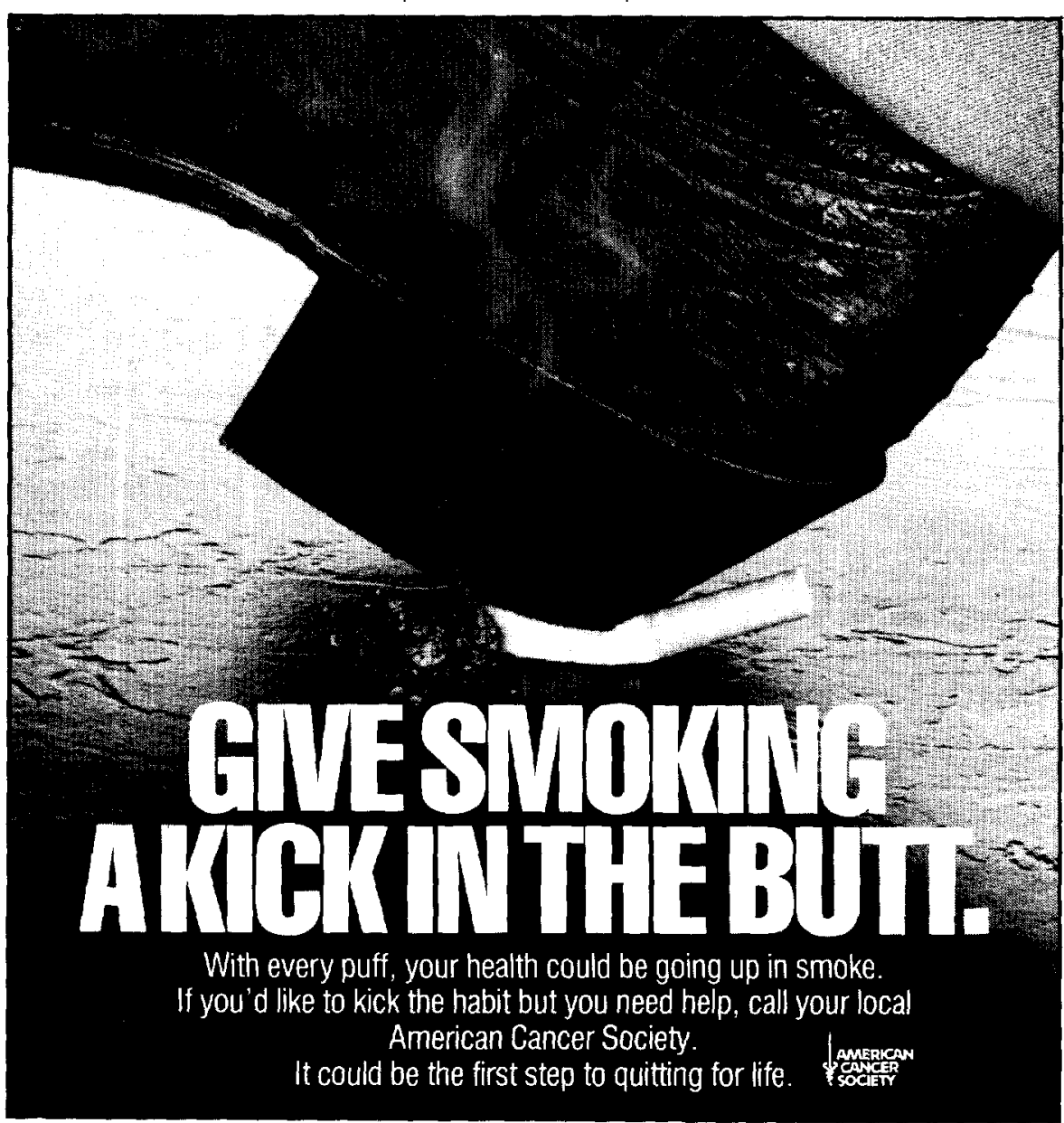

